\title{
The liverwort family Lejeuneaceae (Marchantiophyta) of Mount Lubuk Raya, North Sumatra, Indonesia
}

\author{
ETTI SARTINA SIREGAR ${ }^{\natural}$, NURSAHARA PASARIBU, KHAIRANI \\ Department of Biology, Faculty of Mathematics and Natural Sciences, Universitas Sumatera Utara. Jl. Bioteknologi No.1, Kampus USU Padang Bulan, \\ Medan 20155, North Sumatra, Indonesia. Tel./fax.: +62-61-8211050, `email: etti1 @usu.ac.id
}

Manuscript received: 13 March 2020. Revision accepted: 26 May 2020.

\begin{abstract}
Siregar ES, Pasaribu N, Khairani. 2020. The liverwort family Lejeuneaceae (Marchantiophyta) of Mount Lubuk Raya, North Sumatra, Indonesia. Biodiversitas 21: 2767-2776. Lejeuneaceae is the largest family in the liverworts. Information on the species of Lejeuneaceae in North Sumatra is still less reported, especially in Mount Lubuk Raya has never been reported. Therefore, the aim of this study is to explore the diversity of Lejeuneaceae in Mount Lubuk Raya, North Sumatra. The study was done using survey method by exploring along the hiking tracks on the study site. All the samples found were collected and then identified in the laboratory-based on morphological characters used the existing literature of Lejeuneaceae. Thirty-seven species of Lejeuneaceae, belonging to 18 genera were identified from Mount Lubuk Raya. Eight species are proposed as new reported for Sumatra: Ceratolejeunea belangeriana, Colura vitiensis, Lejeunea curviloba, Lejeunea dipterota, Lepidolejeunea bidentula, Leptolejeunea maculata, Schiffneriolejeunea pulopenangensis, Spruceanthus planiusculus. Identification key of species and pictures of species newly recorded is provided in this paper.
\end{abstract}

Keywords: Diversity, Lejeuneaceae, Mount Lubuk Raya, new records

\section{INTRODUCTION}

Lejeuneaceae with about 69 currently accepted genera and more than one thousand species is one of the largest families in the liverworts (Wang et al. 2016). The members of the family are small to robust size, green, yellowish, brown, black, or whitish in color; branches Lejeunea-type (sometimes with Frullania-type branches). The arrangement of leaves on stem are incubous (when viewed from dorsal, each leaf overlaps the adjacent younger leaf above); lateral leaves are divided into lobe and lobule, the lobules are attached to the lobe along a keel (a fold); the small oil bodies in leaf cells, granular or homogeneous. Underleaves usually present (except in Cololejeunea), undivided or divided. Gynoecia with only 1 archegonium, perianth usually with a beak; capsule rounded, wall 2layered, spores isodiametrical or elongate, multicellular (Gradstein 2011; 2013).

Lejeuneaceae generally grow in humid tropical rainforest, prefer the moist and semi-shaded to shaded places in lowland and submontane rainforests or in secondary vegetation. Some of the species are also found in open and disturbed areas such as in the suburbs and area of cultivated plants. Most of the species belonging to this family are epiphytes on tree trunks, branches of trees or shrubs, living leaves, and some on rotten logs (Gradstein 2001; Lee and Gradstein 2013).

The floristic work on liverworts in Sumatra is still limited. Recent studies in Sumatra especially North Sumatra have reported more data and information of liverworts [eg: Siregar et al. $(2013 ; 2018 ; 2019)$; Pasaribu et al. (2018)]. However, the research and exploration of liverworts especially family Lejeuneaceae in North Sumatra are relatively scanty. Siregar et al. (2014), reported 16 species of Lejeuneaceae subfamily Ptychanthoideae in Sibayak Forest; Dewi (2016) reported 12 species of Lejeuneaceae in Telagah Forest, Gunung Leuser National Park; Siregar et al. (2017), reported 29 species in Sicike-cike Natural Park with 9 new species recorded (new finding in Sumatra, but have been reported to another island); Siregar and Pasaribu (2020) reported 31 species of Lejeuneaceae in Taman Eden Natural Park. Data and information on the liverwort family Lejeuneaceae in Mount Lubuk Raya have not been reported until now, so it needs to be carried out an inventory. Mount Lubuk Raya is a potential habitat for liverworts, especially family Lejeuneaceae. Altitude from lowland to mountain forest, high annual rainfall, high humidity up to $77 \%$, with some slightly open vegetation. Based on this information, it is necessary to conduct the research to explore the diversity of Lejeuneaceae in Mount Lubuk Raya, North Sumatra to enrich the limited information on biodiversity in the area.

\section{MATERIALS AND METHODS}

The study area is located at Mount Lubuk Raya, South Tapanuli, North Sumatra, Indonesia. The area is about $3050 \mathrm{ha}$, at $661-1.892 \mathrm{~m}$ asl., the annual rainfall is about $2.387 \mathrm{~mm} /$ year, the relative humidity ranges from $67-77 \%$ (BPS 2017). Commonly vegetation is Dipterocarpaceae, Moraceae, Euphorbiaceae, Araceae, Arecaceae, Orchidaceae, and Nepenthaceae. 


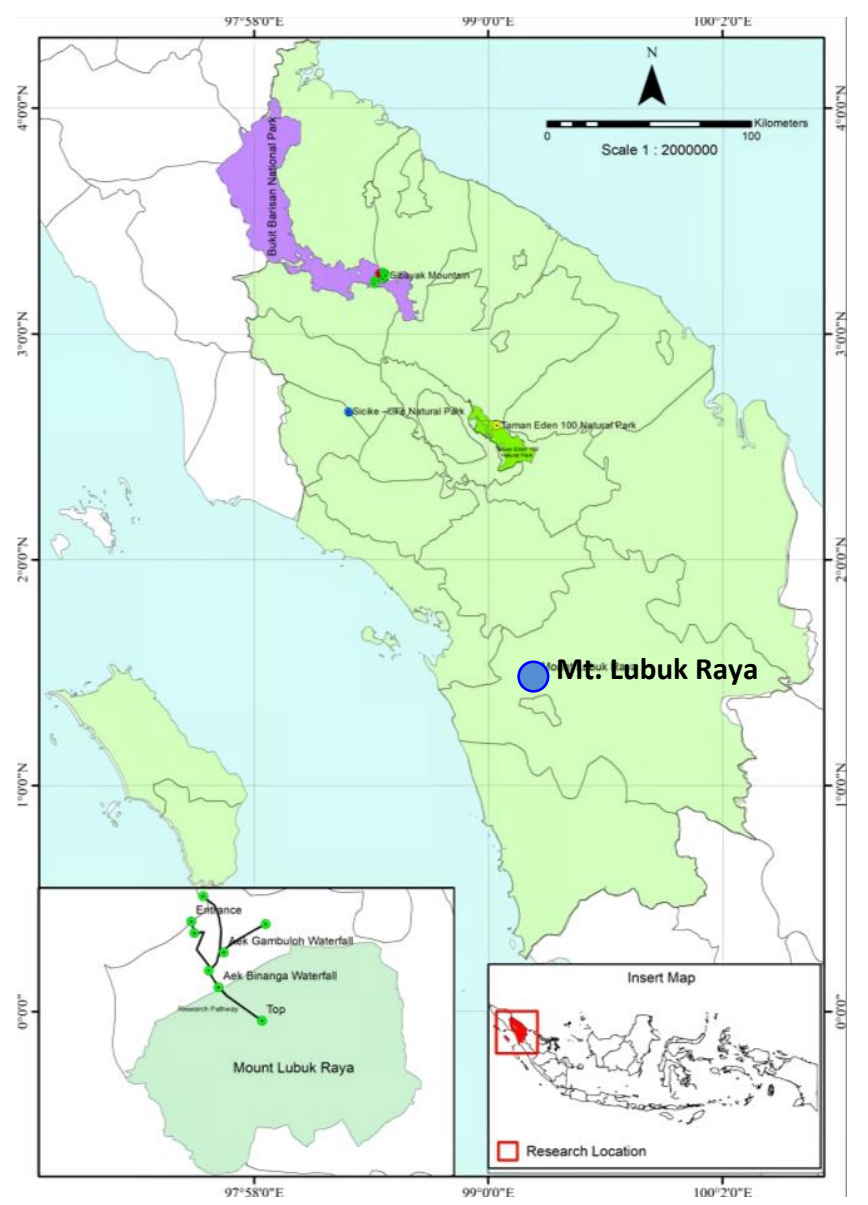

Figure 1. The study area in Mount Lubuk Raya, North Sumatra, Indonesia show the Lejeuneaceae site collection

Samples of Lejeuneaceae were collected in July 2017 by exploring the accessible paths within the research site, mainly along the tracks from lowland to the peak, Aek Gambulo waterfall area, and Aek Binanga Waterfall area (Fig. 1). One hundred fifty-eight newly collected specimens from Mount Lubuk Raya were used for the study. All cited specimens are from the same locality ["Sumatra: North Sumatra: Mt Lubuk Raya"]. Characterization of specimens was conducted by observing the morphological characters using binocular microscope at $40 \mathrm{x}$ to $400 \mathrm{x}$ magnification. All of the newly acquired specimens are deposited at Herbarium Medanense (MEDA), Departement of Biology Faculty of Mathematics and Natural Sciences, Universitas Sumatera Utara, Medan, Indonesia. Key identification and figures of newly recorded species are provided.

\section{RESULTS AND DISCUSSION}

During the study, 37 species of Lejeuneaceae have been found belonging to 18 genera; 8 of them were new records: Ceratolejeunea belangeriana, Colura vitiensis, Lejeunea curviloba, Lejeunea dipterota, Lepidolejeunea bidentula, Leptolejeunea maculata, Schiffneriolejeunea pulopenangensis, Spruceanthus planiusculus.
The check listed of Lejuneaceae collected from the study area were described below, arranged alphabetically. New record species for Sumatra was indicated by an asterisk (“*”) behind the species name.

\section{Key to species}

Key to species of Lejeuneaceae in Mount Lubuk Raya, North Sumatra, Indonesia

1. a. Underleaf absent

b. Underleaf present

Cololejeunea falcata

a. Underleaf divided

b. Underleaf undivided ………………....................... 20

3. a. Leaves suberect, almost parallel to the stem .....

b. Leaves obliquely to widely spreading ……............... 4

4. a. Lateral leaves with an inflated sac at the leaf apex Colura vitiensis

b. Lateral leaves without an inflated sac at the leaf .......... 5

a. One underleaf to each leaf

b. One underleaf to each leaf pair ….......................... 6

6. a. Underleaf lobes form an angle of $35-45^{\circ}$ towards the

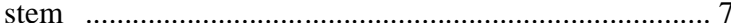

b. Underleaf lobes form an angle of $75^{\circ}-90^{\circ}$ towards the stem

7. a. Leaf lobules never reduced

b. Leaf lobules sometimes reduced ….......................... 13

8. a. Lobules ovate

b. Lobules rectangular …......................................... 10

9. a. Apex of leaf with 1-3 teeth, underleaves large .............. Ceratolejeunea belangeriana

b. Apex of leaf entire, underleaves small Lepidolejeunea bidentula

10. a. Underleaves shallowly bifid to $1 / 7-1 / 5$

b. Underleaves more deeply bifid to $1 / 4_{-1}^{1 / 2}$

Cheilolejeunea incisa Cheilolejeunea trapezia

11. a. Ventral merophyte on main stems 2 cells wide ............ 12

b. Ventral merophyte on main stems more than 2 cells wide

12. a. Lobules small, about $1 / 5$ lobe length, often reduced

b. Lobules $1 / 3$ lobe length, never reduced Lejeunea obscura Lejeunea tuberculosa

13. a. Lateral leaves overlapping ................. Lejeunea dipterota

b. Lateral leaves contiguous or distant ……............. 14

14. a. Trigones distinct …............................... Lejeunea eifrigii

b. Trigones indistinct ……......................................... 15

15. a. Leaves apex incurved ........................ Lejeunea curviloba

b. Leaves apex straight

... 16

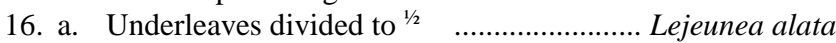

b. Underleaves divided to ${ }^{1 / 4}$....................... Lejeunea sordida

17. a. Leaf apex rounded to acute …………………......... 18

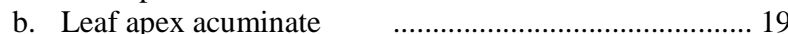

18. a. Underleaf lobes lanceolate, 5 cells long .........................

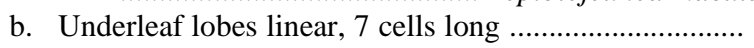
..................................................... Leptolejeunea vitrea

19. a. Underleaf lobes 6 cells long and 2 cells wide ............... Drepanolejeunea levicornua

b. Underleaf lobes 3 cells long and 1cell wide

20. a. Midleaf cells elongate Drepanolejeunea ternatensis

b. Midleaf cells isodiametric 
21. a. Plant dendroid, regularly pinnate branched 22

b. Plant not dendroid, irregularly branched

22. a. Plant with Frullania-type branches, leaves with vitta Dendrolejeunea sp.

b. Plant with Lejeunea-type branches, leaves without vitta $\quad$......................................... Ptycanthus striatus

23. a. Plant green to black, rather flat when dry (Mastigolejeunea) 24

b. Plant green to brown, worm-like when dry .................. 25

24. a. Margin of underleaf toothed, apex curved

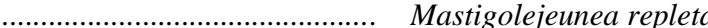

b. Margin of underleaf entire, apex plane Mastigolejeunea virens

25 a. Stem fragile, Lobule ovate ........ Acrolejeunea pycnoclada

b. Stem rigid, Lobule oblong $\quad$.................................... 26

26. a. Margin of underleaves entire ...... (Schiffneriolejeunea) 27

b. Margin of underleaves toothed ......... (Thysananthus) 28

27. a. Free margin of lobule involute

Schiffneriolejeunea tumida

b. Free margin of lobule plane Schiffneriolejeunea pulopenangenis

28. a. Leaves with a long vitta ............. Thysananthus retusus

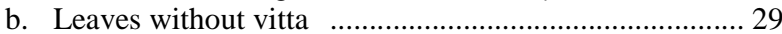

29. a. Upper part of leaf curved and symmetric ..................

Thysananthus convolutus

b. Upper part of leaf plane and asymmetric ....................................... Thysananthus spathulistipus

30 a. Ventral merophyte 4-5 cells wide .......................... 31

b. Ventral merophyte 6-8 cells wide ………................. 35

31. a. Apex of the leaf lobule attached to the leaf lobe by one cell 32

b. Apex of the leaf lobule attached to the leaf lobe by 2-3 cells ... 33

32. a. Underleaves imbricate, large, 5-6 $\mathrm{x}$ as wide as the stem ....................................... Lopholejeunea eulopha

b. Underleaves distant to contiguous, 2-3 as wide as the stem .................................... Lopholejeunea nigrican

33 a. Apex of leaves incurved .......... Lopholejeunea zollingeri

b. Apex of leaves plane ............................................ 34

34. a. Underleaves 4 times stem width

b. Underleaves 5-6 times stem width

Lopholejeunea subfusca

Lopholejeunea wiltensi

35. a. Leaves and underleaves margin entire ….................. 36

b. Leaves and underleves margin toothed ................ Spruceanthus polymorphus

36. a. Perianth with 6 smooth keel

Spruceanthus planiusculus

b. Perianth with 10 smooth keel …….... Spruceanthus $\mathrm{sp}$

\section{Acrolejeunea pycnoclada (Tayl.) Schiffn.}

The species is characterized by the ovate leaf lobes, apex rounded and recurved; lobules apex obtuse, with 2-3 teeth, one cell long; apex of underleaves entire and recurved. Grows on tree trunks, at $621-823 \mathrm{~m}$ a.s.1.

Specimens examined: Khairani 56, 57, 137, 152, 153, 158.

Distribution: Australia, Borneo, Indo-Malesia, Indonesia (Sumatra, Java, West Irian), Philippines, the Pacific region, tropical Africa, Vietnam (Gradstein et al. 2002; Wang et al. 2016).

\section{Ceratolejeunea belangeriana (Gottsche) Steph*}

Figure 2.A-F

The species is characterized by the leaf lobes ovate to oblong, margin entire with 1-3 teeth in apices, apex obtuse, and recurved; perianths with 4 keels. Grows on tree trunks, at $778-1280 \mathrm{~m}$ a.s.1.

Specimens examined: Khairani 14, 185.

Distribution: Comores, Indomalaya from Thailand to the Philippines and New Guinea, Indonesia (Sumatra: new record, Java), Madagascar, Mauritius, Melanesia, Polynesia, Réunion, Seychelles (Gradstein 2011; Pócs 2011).

\section{Cheilolejeunea incisa (Gottsche) R.M.Schust \& Kachroo}

The species is characterized by the very short bifid apex of underleaves, $1 / 5$ to $1 / 7$ of underleaves. Grows on tree trunks, and leaves, at $621-823 \mathrm{~m}$ a.s.1.

Specimens examined: Khairani 141, 160.

Distribution: Australia, New Guinea, Indonesia (Sumatra, Java) (Thiers 1992), India (Singh Deo and Singh 2013), North Borneo (Mizutani 1970, as C. excisula).

\section{Cheilolejeunea trapezia (Nees) Kachroo \& R.M.Schust.}

The species is characterized by the ovate leaves; leaf lobules large oblong to rectangular, $2 / 3$ lobe length. Grows on tree trunks, and leaves, at 621-1280 m a.s.l.

Specimens examined: Khairani 12, 30, 59, 74, 86, 96, 100, 129, 155, 161, 166, 172, 183 .

Distribution: Australia, Bangladesh, Borneo, China, Cambodia, India, Indonesia (Sumatra, Java, Celebes), Japan, Kampuchea, Malaysia, New Guinea, New Caledonia, Micronesia, Thailand, the Philippines, Samoa, Sri Lanka, Vietnam (Eggers 2006; Zhu and So 2001; Daniels and Kariyappa 2013).

\section{Cololejeunea falcata (Horik.)) Benedix}

The species is characterized by the oblong and falcate leaf lobes, vitta present 2-3 cell rows wide; without underleaves. Grows on leaves, at 939-1162 m a.s.1

Specimens examined: Khairani 117, 122, 168.

Distribution: Borneo, Cambodia, China, Indonesia (Java, Sumatra), Japan, New Caledonia, Madagascar, Malaysia, Philippines, Sri Lanka, Taiwan, Thailand, Vietnam (Pócs et al. 2011).

\section{Colura vitiensis Pocs \& J. Eggers*}

Figure 3.A-D

The species is characterized by the ovate leaf lobes, the sac acutely papillose with \pm 26 cells; underleaves $\mathrm{V}$ shaped, lobes lanceolate. Grows on leaves, at 829-1162 m a.s.1.

Specimens examined: Khairani 32, 33122.

Distribution: Fiji, Solomon Is, Indonesia (Sumatra: new record) (Pócs 2013).

\section{Dendrolejeunea sp.}

The species is characterized by the dendroid plant; ventral merophyte about 12 cell rows wide; leaf lobes ovate, vitta present, 8-10 cells long and 2-3 cells wide; apex of leaf lobules truncate with 2 teeth, second tooth 3 cells long and 1 cell wide. Grows on tree trunks, at $991 \mathrm{~m}$ a.s.1.

Specimen examined: Khairani 169. 


\section{Diplasiolejeunea cavifolia Steph.}

The species is characterized by the ovate and convex leaf lobes; leaf lobule ovate, $1 / 3$ to $1 / 2$ lobe length, apex truncate, with 3 teeth, second tooth 3 cells long, 2 cells wide, distance between teeth 4 cell rows; underleaves cuneate, lobes triangular, 16 cells long, 8 cells wide. Grows on leaves, at $974 \mathrm{~m}$ a.s.l.

Specimen examined: Khairani 85.

Distribution: Pantropical; from Asia known from Cambodia, China, Luzon, Indonesia (Sumatra, Java, Bali), Malaysia, New Caledonia, Sri Lanka, Taiwan (SchäferVerwimp 2006).

\section{Drepanolejeunea levicornua Steph.}

The species is characterized by the serrate leaf margin; underleaves distant, bilobed to the base, lobes linear to lanceolate, 6 cells long, 2 cells wide. Grows on leaves, at 939-1106 m a.s.l.
Specimens examined: Khairani 97, 108, 110.

Distribution: Borneo, China, Indonesia (Sumatra, Java, Celebes), New Guinea, Malaysia, China (Zhu and So 2001; Siregar et al. 2017).

\section{Drepanolejeunea ternatensis (Gottsche) Schiffn.}

The species is characterized by the ovate leaf lobes, apex acuminate; underleaves distant, bilobed $1 / 2$ to $1 / 3$ lobe length, lobes linear, 3 cells long, 1 cell wide. Grows on leaves, at $621 \mathrm{~m}$ a.s.l.

Specimen examined: Khairani 137.

Distribution: Australia, Africa, Caroline Islands, China, Fiji, India, Indonesia (Sumatra, Java, Moluccas), Japan, Malaysia, Micronesia, New Guinea, Philippines, Samoa, Seychelles, Sri Lanka (Zhu and So 2001; Dey et al. 2013; Siregar et al. 2017).

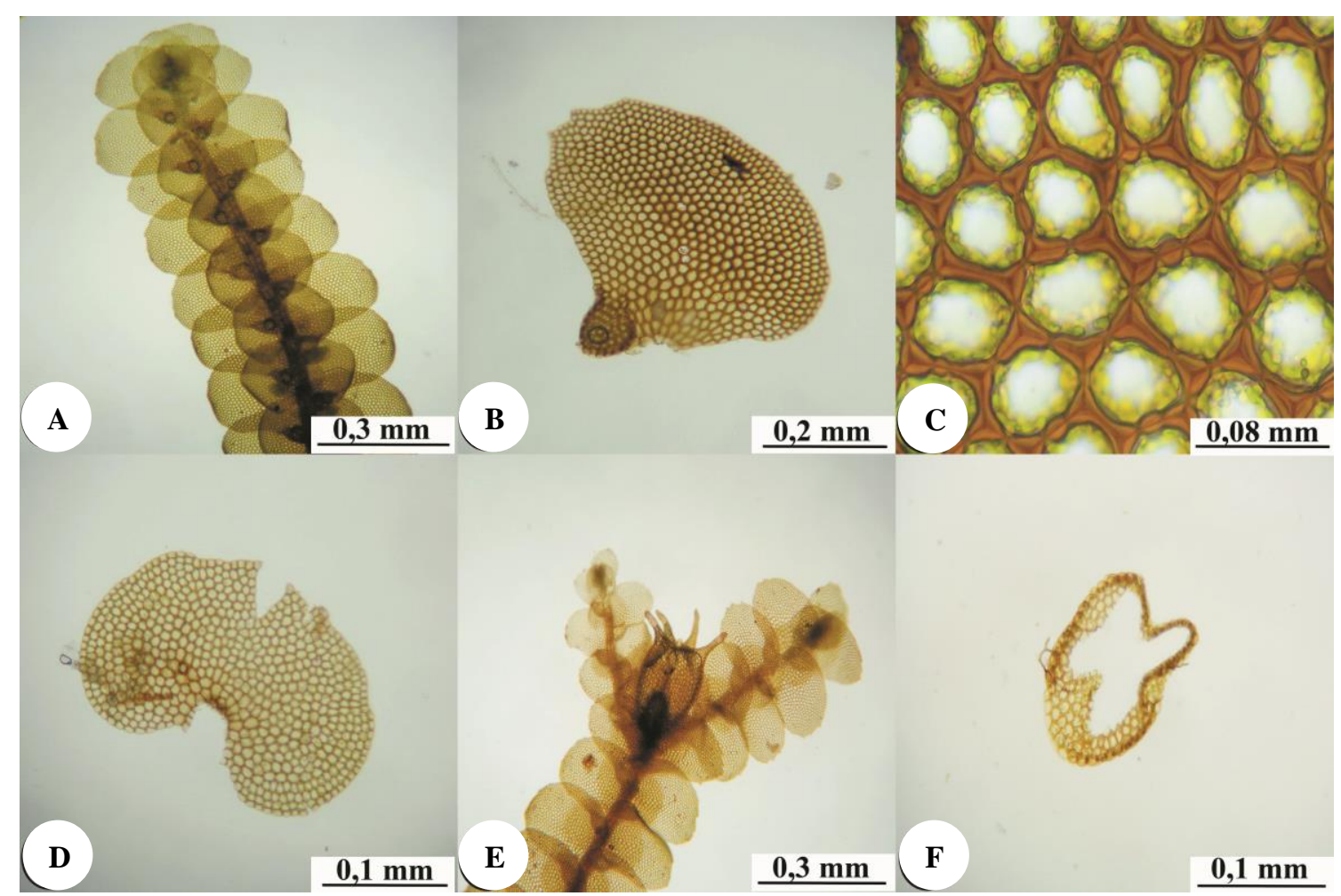

Figure 2. Ceratolejeunea belangeriana. A. Habit, B. Lateral leaf, C. Leaf cells, D. Underleaf, E. Perianth, F. Perianth keel (Khairani 14)

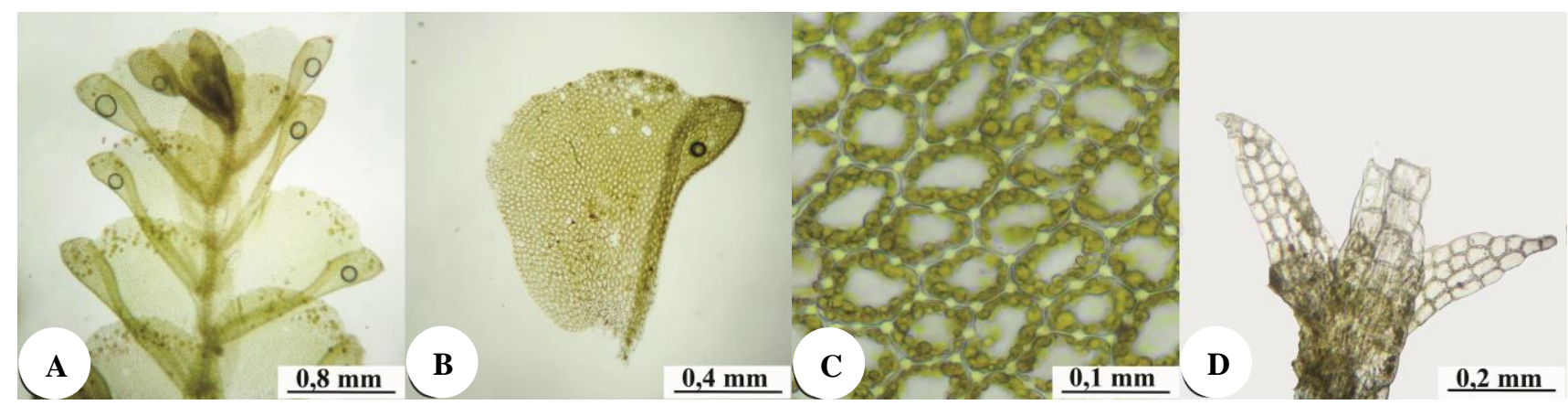

Figure 3. Colura vitiensis. A. Habit, B. Lateral leaf, C. Leaf cells, D. Underleaf (Khairani 32) 


\section{Lejeunea alata Gottsche.}

The species is characterized by the ovate leaf lobes; lobules $1 / 3$ lobe length, apex truncate with 2 teeth. Grows on leaves, at $1106 \mathrm{~m}$ a.s.l.

Specimen examined: Khairani 175.

Distribution: Africa, Indonesia (Sumatra, Java), Samoa, New Guinea, Malaysia, Vietnam, (Zhu and So 2001; Lee 2013).

\section{Lejeunea curviloba Steph*}

Figure 4.A-D

The species is characterized by the rounded apex and incurved leaf lobes; lobules small, $1 / 4$ to $1 / 2$ lobe length; underleaves bilobed to1/2 lobe length. Grows on leaves, at $1280 \mathrm{~m}$ a.s.l.
Specimen examined: Khairani 128.

Distribution: Bhutan, China, India, Indonesia (Sumatra: new record), Japan (Zhu and So 2001).

\section{Lejeunea dipterota (Eifrig) G.E.Lee*}

Figure 5.A-F

The species is characterized by the contiguous and large underleaves, 4 times as wide as the stem; perianth ovateoblong, with 5 keels, bracts in 2 pairs. Grows on tree trunks and leaves, at 621-1280 $\mathrm{m}$ a.s.l.

Specimens examined: Khairani 06, 07, 11, 15, 17, 19, $21,34,39,42,57,60,61,67,71,73,134,146,148,157$, $159,181,182$.

Distribution: Indonesia (Sumatra: new record, Java), Malaysia (Lee 2013).

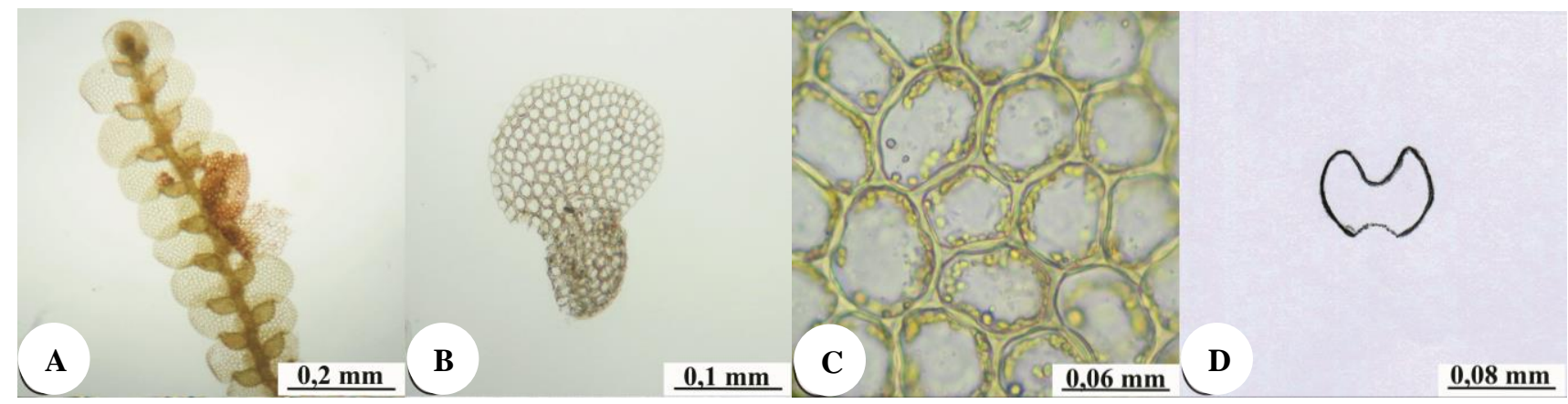

Figure 4. Lejeunea curviloba. A. Habit, B. Lateral leaf, C. Leaf cells, D. Underleaf (Khairani 128)

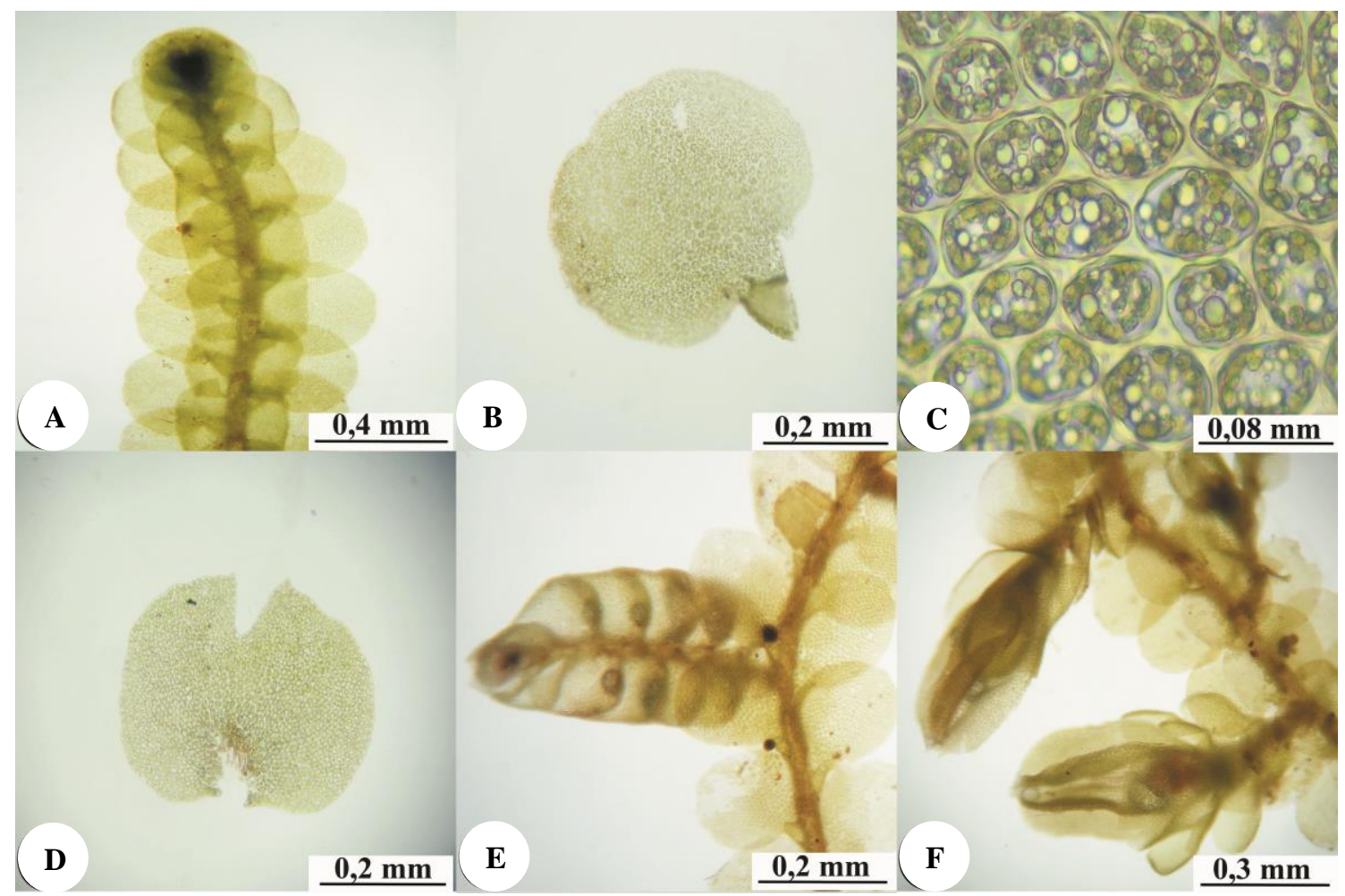

Figure 5. Lejeunea dipterota. A. Habit, B. Lateral leaf, C. Leaf cells, D. Underleaf, E. Androecium, F. Perianth (Khairani 06) 


\section{Lejeunea eifrigii Mizut.}

The species is characterized by the ovate leaf lobes, apex obtuse; leaf cells usually without distinct trigones; underleaves distant and small. Grows on tree trunks, and leaves, at 1000-1162 m a.s.l.

Specimens examined: Khairani 106, 122, 125.

Distribution: Borneo, China, India, Indonesia (Sumatra, Java), Japan, New Caledonia, Papua New Guinea, Peninsular Malaysia, Philippines, Vietnam (Zhu and So 2001; Lee et al. 2011; Shu et al. 2017).

\section{Lejeunea obscura Mitt.}

The species is characterized by the ovate to triangular leaf lobules, reduced to $1 / 5$ lobe length; underleaves distant, apex divided to $1 / 2$ lobe length. Grows on tree trunks, at 621-939 m a.s.1.

Specimens examined: Khairani 76, 136.

Distribution: China, India, Indonesia (Sumatra, Java), Nepal, Sri Lanka (Zhu and So 2001; Siregar et al. 2017).

\section{Lejeunea sordida (Nees) Nees}

The species is characterized by the large and contiguous underleaves, apex divided to1/4 of lobe length. Grows on tree trunks, at 797-1000 m a.s.1.

Specimens examined: Khairani 55, 93.

Distribution: Africa, Australia, Borneo, Caroline Islands., China, Fiji, Indonesia (Sumatra, Java), Japan, Micronesia, New Caledonia, Papua New Guinea, Peninsular Malaysia, Philippines, Samoa, Solomon Islands, Thailand (Lee et al. 2011; Lee and Pócs 2018).

\section{Lejeunea tuberculosa Steph.}

The species is characterized by the ovate leaf lobes, apex rounded; leaf lobules ovate, $1 / 3$ lobe length, apex truncate with 2 teeth, 2 cells long, 1 cell wide. Grows on tree trunks, at $823 \mathrm{~m}$ a.s.l.

Specimen examined: Khairani 64.

Distribution: Africa, Bhutan, China, India, Indonesia (Sumatra, Java), Malaya, Nepal, Philippines, Thailand, Vietnam (Lee et al. 2014; Shu et al. 2017).

\section{Lepidolejeunea bidentula (Steph.) R.M. Schust* Figure 6.A-D}

The species is characterized by the triangular to ovate leaf lobules, apex truncates with two teeth; trigones triangular; underleaves small, two times as wide as the stem. Grows on tree trunks, at 829-991 m a.s.l.

Specimens examined: Khairani 84, 90, 167, 170.

Distribution: Australia, Cambodia, Caroline Islands, China, Fiji, India, Taiwan, Indonesia (Sumatra: new record, Java), Japan, Madagascar, Malaysia, New Caledonia, Papua New Guinea, Philippines, Seychelles, Solomon Islands, Sri Lanka, Thailand, Vietnam (Zhu and So 2001; Wang et al. 2011; Singh and Singh 2016; Shu et al. 2017).

\section{Leptolejeunea maculata (Mitt.) Schiffn*}

\section{Figure 7.A-D}

The species is characterized by the oblong leaves, margin dentate, apex acute; trigones large, usually nodulose; underleaves deeply bilobed, lobes lanceolate. Grows on leaves, at $1106 \mathrm{~m}$ a.s.l.

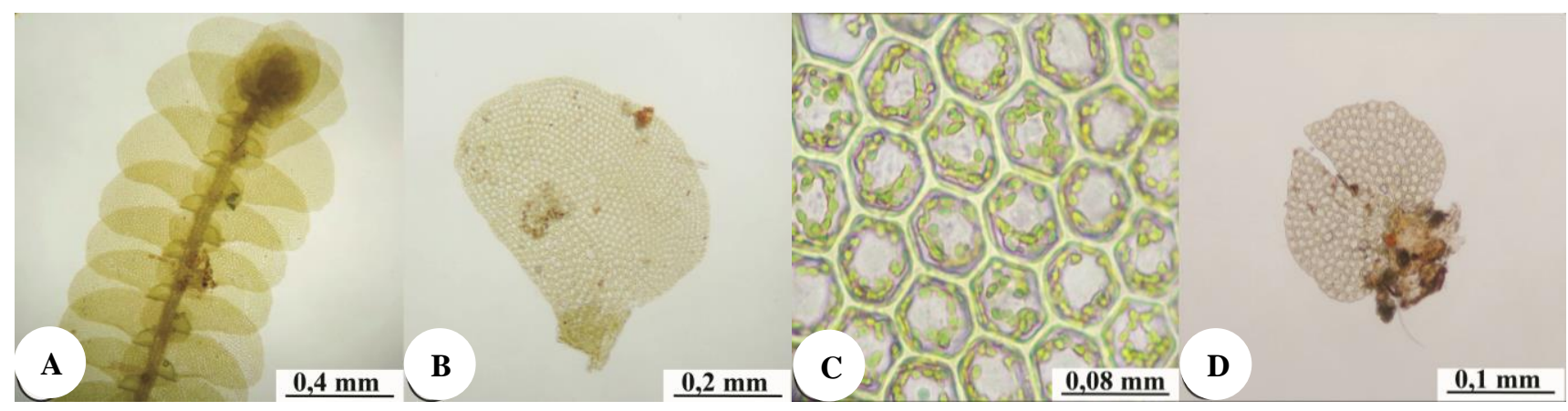

Figure 6. Lepidolejeunea bidentula. A. Habit, B. Lateral leaf, C. Leaf cells, D. Underleaf (Khairani 90)

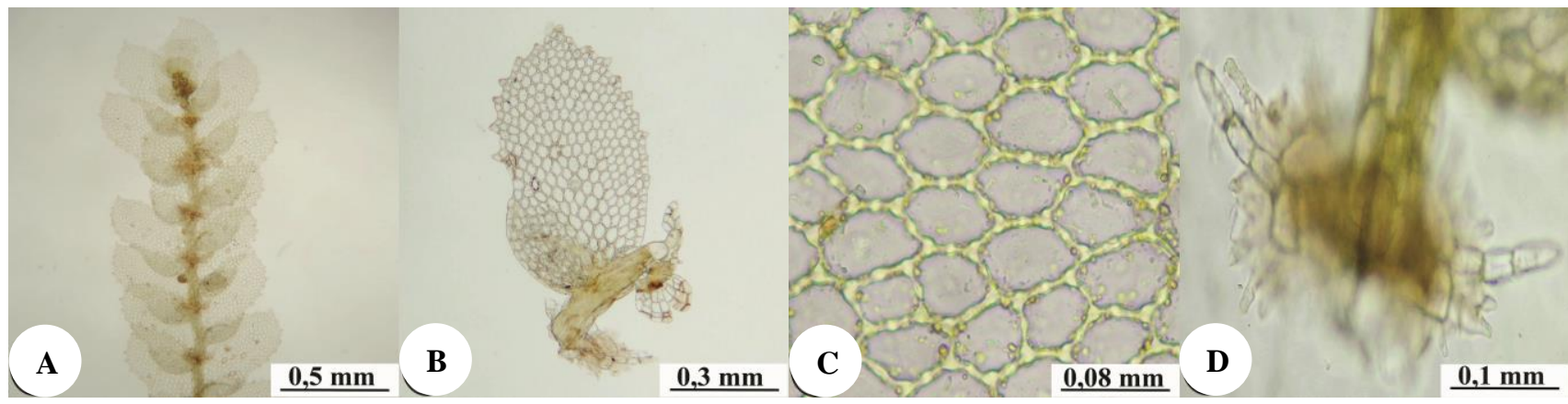

Figure 7. Leptolejeunea maculata. A. Habit, B. Lateral leaf, C. Leaf cells, D. Underleaf (Khairani 108) 
Specimen examined: Khairani 108.

Distribution: Indonesia (Sumatra: new record, Java, Moluccas, Celebes), Malaysia, Papua New Guinea, Vietnam (Zhu and So 2001; Eggers 2006; Haerida 2009; Pócs et al. 2013; Bechteler et al. 2016).

\section{Leptolejeunea vitrea (Nees) Schiffn.}

The species is characterized by the oblong leaf lobe, apex rounded; trigones usually nodulous; underleaves distant, lobes linear, 7 cells long and 2 cells wide. Grows on leaves, at 1000-1280 m a.s.l.

Specimens examined: Khairani 100, 128, 173.

Distribution: Indonesia (Sumatra, Java, Moluccas), Malaysia, Philippines, Vietnam (Eggers 2006).

\section{Lopholejeunea eulopha (Tayl.) Schiffn.}

The species is characterized by the large underleaves, 56 times stem width; leaves oblong; lobule apex attached to the leaf lobe across by a single cell. Grows on tree trunks, at $778 \mathrm{~m}$ a.s.1.

Specimens examined: Khairani 08.

Distribution: Australia, Borneo, China, India, Indonesia (Sumatra, Java, Bali, Celebes, Moluccas), Japan, Papua New Guinea, Pacific Islands, Philippines, Solomon Islands, Sri Lanka, tropical Africa, tropical America (Zhu and Gradstein 2005; Haerida et al. 2010).

\section{Lopholejeunea nigricans (Lindenb.) Schiffn.}

The species is characterized by the ovate leaf lobes; lobules $1 / 3-2 / 5$ lobe length, apex attached to the leaf lobe across by a single cell; trigones indistinct; underleaves distant and small, three times stem width. Grows on tree trunks, at $778 \mathrm{~m}$ a.s.l.

Specimen examined: Khairani 01, 29, 88, 89, 121.

Distribution: Australia, Bhutan, Borneo, China, India, Indonesia (Sumatra, Java, Celebes, Moluccas), Japan, Malaysia, Nepal, Papua New Guinea, Philippines, tropical Africa, tropical America (Zhu and Gradstein 2005; Haerida et al. 2010).

\section{Lopholejeunea subfusca (Nees) Schiffn.}

The species is characterized by the ovate and truncate leaf lobules, apex attached to the leaf lobe across 2 cells, with one tooth; underleaves 4 times stem width. Grows on tree trunks, at 621-1162 $\mathrm{m}$ a.s.l.

Specimens examined: Khairani 02, 05, 11, 30, 64, 69, 77, 80, 91, 99, 102, 115, 124, 135, 137, 144, 149, 150, 151.

Distribution: Pantropical, in Asia: Bangladesh, Bhutan, Cambodia, China, Singapore, India, Indonesia (Sumatra, Java, Bali, Celebes, Moluccas), Japan, Malaysia, Nepal, Philippines, Sri Lanka, Thailand, Vietnam (Zhu and Gradstein 2005; Haerida et al. 2010).

\section{Lopholejeunea wiltensii Steph.}

The species is characterized by the large underleaves, 56 times stem width; base of lobule inflated, apex of leaf lobule attached to the lobe across 3 cells. Grows on tree trunks, at 778-1000 $\mathrm{m}$ a.s.1.
Specimens examined: Khairani 04, 16, 54, 65, 66, 68, 70, 78, 83, 98, 107.

Distribution: Borneo, China, Fiji, Indonesia (Sumatra, Java, Celebes), Japan, Malaysia, Papua New Guinea, Philippines, Sri Lanka, Thailand (Zhu and Gradstein 2005; Haerida et al. 2010).

\section{Lopholejeunea zollingeri (Steph.) Schiffn.}

The species is characterized by the recurved apex of leaf-lobe, apex of the lobule attached to the leaf lobe across 2-3 cells; underleaves contiguous, 5 times as wide as the stem. Grows on tree trunks, at $778 \mathrm{~m}$ a.s.l.

Specimens examined: Khairani 09.

Distribution: Borneo, China, Fiji, Indonesia (Sumatra, Java, Celebes), Japan, Malaysia, Papua New Guinea, Philippines, Sri Lanka, Thailand (Zhu and Gradstein 2005; Haerida et al. 2010).

\section{Mastigolejeunea repleta (Tayl.) A. Evans}

The species is characterized by the large ventral merophyte, 10 cells wide; leaf lobes oblong, apex acute; leaf lobule small, 1/4 of lobe length. Grows on tree trunks, at $621-778 \mathrm{~m}$ a.s.1.

Specimens examined: Khairani 08,139.

Distribution: Australia, Bhutan, China, French Polynesia, India, Indonesia (Sumatra, Java, Kalimantan, West Papua), Japan, Malaysia, Nepal, New Caledonia, Papua New Guinea, Philippines, Solomon Islands, Sri Lanka, Taiwan, Thailand, Vietnam (Sukkharak and Gradstein 2014).

\section{Mastigolejeunea virens (Angstr.) Steph.}

The species is characterized by the ovate to oblong of leaf lobes, bases auriculate; apex of lobule obliquely truncate, with one long tooth, 4-6 cells long. Grows on tree trunks, at $1280 \mathrm{~m}$ a.s.l.

Specimen examined: Khairani 184.

Distribution: Australia, French Polynesia, India, Indonesia (Sumatra, Java, Bali, Kalimantan, Celebes, Moluccas, West Papua), Malaysia, Micronesia, New Caledonia, Papua New Guinea, Philippines, Samoa, Seychelles, Solomon Islands, Sri Lanka, Thailand, Tonga, Vietnam (Gradstein et al. 2002; Sukkharak and Gradstein 2014).

\section{Metalejeunea cucullata (Reinw. et al.) Grolle}

The species is characterized by: the arrangement of leaves is parallel to the stem; leaf lobules are very large on the main stem, $1 / 2$ to $3 / 4$ of lobe length. Grows on tree trunks, at $1162 \mathrm{~m}$ a.s.1.

Specimen examined: Khairani 124.

Distribution: Pantropics.

\section{Ptychanthus striatus (Lehm \& Lindenb) Nees}

The species is characterized by the Frullania type branching; leaf lobes ovate, base auriculate, margin entire or toothed near apex; underleaves contiguous, base auriculate. Grows on tree trunks, at $939 \mathrm{~m}$ a.s.l.

Specimen examined: Khairani 164. 
Distribution: Australasia, Borneo, China, India, Indonesia (Sumatra, Java, Celebes, Moluccas), Japan, Malaysia, New Caledonia, Oceania, Papua New Guinea, Philippines, Taiwan, Thailand, Sri Lanka, tropical Africa (Gradstein et al. 2002; Haerida et al. 2010; Kornochalert et al. 2012; Wang et al. 2014).

\section{Schiffneriolejeunea pulopenangensis (Gottsche) Gradst.* Figure 8.A-D}

The species is characterized by the auriculate of dorsal leaf base, margin entire and rolled inwards; trigones cordate; the lobule apex truncates with 2 teeth; underleaves rolled inwards. Grows on tree trunks, at $778-823 \mathrm{~m}$ a.s.1.

Specimens examined: Khairani 13, 24, 45, 47, 53.

Distribution: China, India, Indonesia (Sumatra: new record, Java, Moluccas), Japan, New Caledonia, north Borneo, northern Australia, Papua New Guinea, Sri Lanka (Haerida et al. 2010; Manju et al. 2012; Gradstein 2015; Wang et al. 2016).

\section{Schiffneriolejeunea tumida (Nees) Gradst.}

The species is characterized by the ovate leaf lobes, dorsal base auriculate, margin entire, rolled inwards especially along of ventral and apical margin. Grows on tree trunks, at 778-797 $\mathrm{m}$ a.s.1.

Specimens examined: Khairani 06, 23, 41.

Distribution: Indonesia (Sumatra, Java, Kalimantan, Celebes), Malaysia (Gradstein 2015).

\section{Spruceanthus planiusculus (Mitt.) X.Q.Shi, R.L.Zhu \& Gradst.* \\ Figure 9.A-F}

The species is characterized by the recurved and auriculate dorsal base of leaves; leaf lobule small, 1/6 to $1 / 3$ lobe length; trigones small; bracts of perianth in 2 pairs, with 8 keels. Grows on tree trunks, at 939 m a.s.l.

Specimen examined: Khairani 79.

Distribution: widespread in the Indopacific region, China (Wang et al. 2016), Indonesia (Sumatra: new record, Java) (Gradstein 2011, as Archilejeunea planiuscula), India, Myanmar, Papua New Guinea (Singh and Kumar, 2016), Vietnam (Shu et al. 2017).

\section{Spruceanthus polymorphus (Sande Lac.) Verd.}

The species is characterized by the broadly ovate of dorsal leaf lobes, apex toothed; underleaves with serrate margin; androecia in spikes with 13 pairs of bracts; gynoecia on main stem; perianths with 5-6 keels. Grows on tree trunks, at $1127-1568 \mathrm{~m}$ a.s.l.

Specimens examined: Khairani 120, 131.

Distribution: Australia, Borneo, India, Indonesia (Sumatra, Java, Celebes), Japan, Pacific, Papua New Guinea, Philippines, Solomon Islands, Taiwan, Thailand, (Gradstein et al. 2002; Haerida et al. 2010).

\section{Spruceanthus sp.}

The species is characterized by the ovate to oblong leaf lobes; leaf lobules ovate, 1/4 lobe length; androecia axillar, in spikes with 6 pairs of bracts; perianth axillar, with 10 keels. Grows on tree trunks, at 829-865 m a.s.1.

Specimens examined: Khairani 26, 187.

\section{Thysananthus convolutus Lindenb.}

The species is characterized by the strongly convex leaves, asymmetric leaf lobe, apex shortly acute and recurved; margin of lobules inrolled; underleaves with recurved apex. Grows on tree trunks, at $797 \mathrm{~m}$ a.s.1.

Specimens examined: Khairani 36, 38, 46, 48.

Distribution: China, India, Indonesia (Sumatra, Java, Moluccas, Celebes, West Papua), Malaysia, Papua New Guinea, Philippines, Solomon Islands, Thailand, (Sukkharak 2015; Wang et al. 2016).

\section{Thysananthus retusus (Reinw et al.) B. Thiers \& Gradst.}

The species is characterized by having vitta on the leaves, (1/2)-2/3 of lobe length, base auriculate; lobules rectangular, with 1 long tooth, 8 cells long; underleaves obdeltoid, base rounded, apex retuse. Grows on tree trunks, at $865 \mathrm{~m}$ a.s.l.

Specimen examined: Khairani 31.

Distribution: Australia, China, India, Indonesia (Sumatra, Java), Japan, Pacific Islands, Papua New Guinea, Philippines, Solomon Islands, Thailand, (Gradstein et al. 2002; Haerida et al. 2010; Sukkharak 2015; Wang et al. 2016).

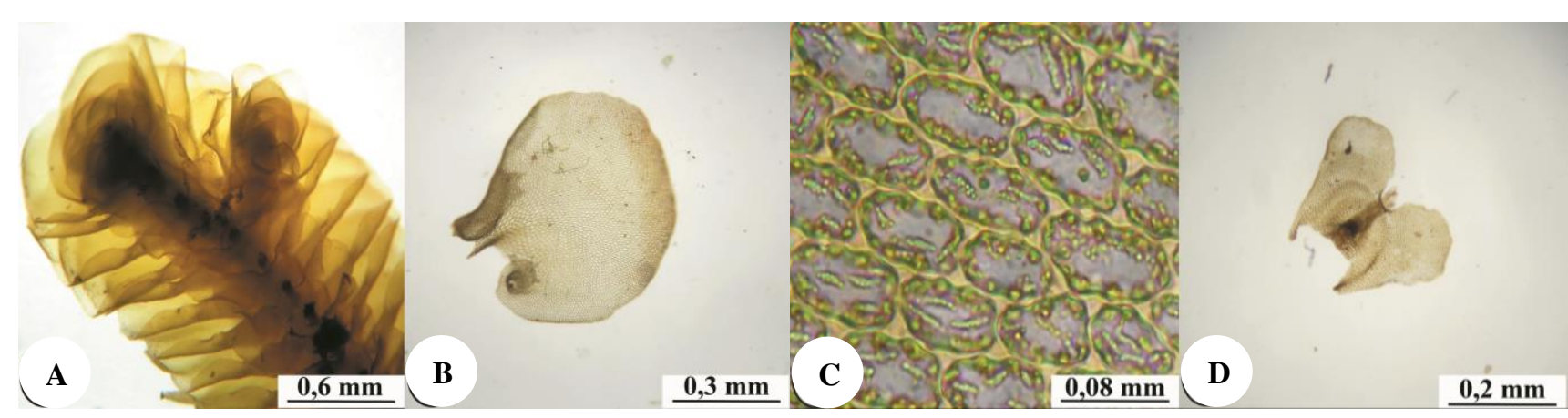

Figure 8. Schiffneriolejeunea pulopenangensis. A. Habit, B. Lateral leaf, C. Leaf cells, D. Underleaf (Khairani 53) 


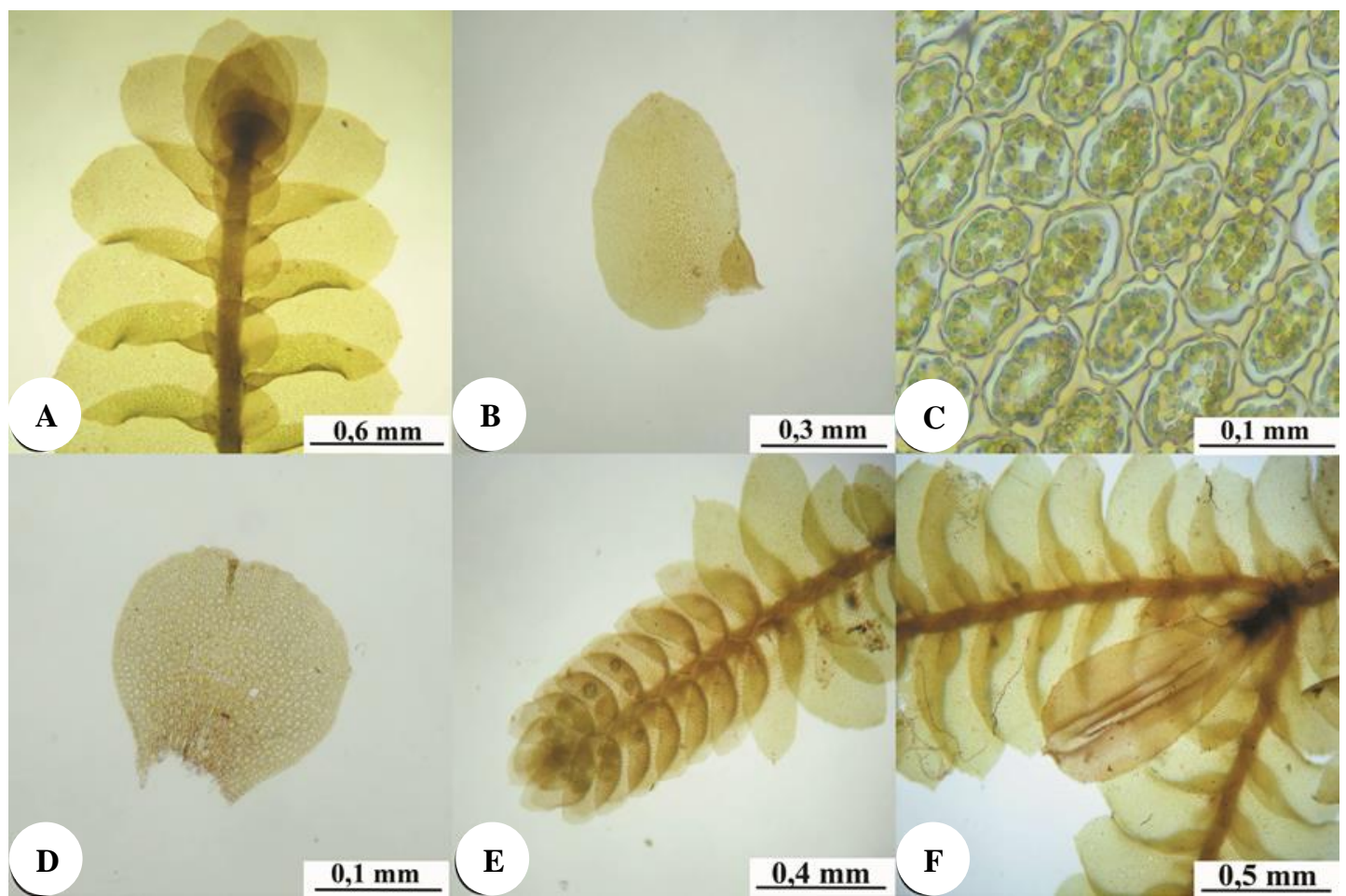

Figure 9. Spruceanthus planiusculus. A. Habit, B. Lateral leaf, C. Leaf cells, D. Underleaf, E. Androecium, F. Perianth (Khairani 79)

\section{Thysananthus spathulistipus (Reinw et al.) Lindenb.}

The species is characterized by the toothed margin of leaves and underleaves; underleaves contiguous, spathulate. Grows on tree trunks, at 621-1568 $\mathrm{m}$ a.s.1..

Specimens examined: Khairani 03, 06, 18, 22, 25, 27, $40,43,49,51,58,62,63,81,113,131,132,133,140,142$, $143,167$.

Distribution: Australia, Borneo, China, India, Indonesia (Sumatra, Java, Bali), Malaysia, New Zealand, Papua New Guinea, Sri Lanka, Solomon Islands, Thailand (Gradstein et al. 2002; Haerida et al. 2010; Renner \& De Lange 2011; Wang et al. 2016).

\section{Recommendations}

Thirty-seven species of Lejeuneaceae were identified in the study, including 8 species as new records for Sumatra. All of the species found in the study grow on the tree trunks and leaves. Therefore, sustainable conservation of Mount Lubuk Raya area is important due to preserve the liverworts diversity especially Lejeuneaceae. Illegal logging, conversion of the area into plantation, human intervention, and also natural disasters affected the normal vegetation. This is a threat to the survival of liverworts, mainly the epiphytic ones, because these plants are very sensitive to deforestation.

The high number of new records species for Sumatra support the notation that liverworts of Sumatra were under collected, and more comprehensive studies in other areas are needed to complete the liverworts data of Sumatra. Studies on the liverworts of Sumatra should speed up competing with the disturbance of the forest areas.

\section{ACKNOWLEDGEMENTS}

The authors would like to express the highest gratitude to Rector of Universitas Sumatera Utara who gave research funding through TALENTA 2017 with contract number /UN5.1.R/PPM/2017 May 22 ${ }^{\text {th }}$ 2017. The authors would also like to thank the officials and field assistants for their permit and aids during exploration in Mount Lubuk Raya, North Sumatra.

\section{REFERENCES}

Badan Pusat Statistik [BPS]. Kabupaten Tapanuli Selatan. 2017. BPS, Tapanuli Selatan. https://tapanuliselatankab.bps.go.id/frontend. [Indonesian]

Bechteler J, Schäfer-Verwimp A, Lee GE, Feldberg K, Pérez-Escobar OA, Pócs T, Peralta DF, Renner MAM, Heinrichs J. 2016. Geographical structure, narrow species ranges, and Cenozoic diversification in a pantropical clade of epiphyllous leafy liverworts. Ecol Evol: 1-16. DOI: $10.1002 /$ ece 3.2656

Daniels AED, Kariyappa KC. 2013. Cheilolejeunea trapezia (Nees) Kachroo \& R.M. Schust. ex Mizut. var. ceylanica (Gottsche) A.E.D. Daniels \& K.C. Kariyappa comb. et stat. nov. (Lejeuneaceae) from India. Taiwania 58 (2): 140-145.

Dewi S. 2016. The species of Lejeuneaceae (Marchantiophyta) at Telagah Forest Gunung Leuser National Park. [Hon. Thesis]. Universitas Sumatera Utara, Medan. [Indonesian]

Dey M, Singh D, Singh DK. 2013. The genus Drepanolejeunea (Marchantiophyta: Lejeuneaceae) in India with a note on three new additions from Eastern Himalaya. Trop Bryol 35: 14-25.

Eggers J. 2006. New bryophyte taxon records for tropical countries 6 . Trop Bryol 27: 107-111.

Gradstein SR, Churchill SP, Salazar-Allen N. 2001. Guide to the Bryophytes of Tropical America. The New York Botanical Garden Press, New York. 
Gradstein SR, Pippo S, Mizutani M. 2002. Bryophyte flora of the Huon Peninsula, Papua New Guinea. LXVIII. Lejeuneaceae subfamily Ptychanthoideae (Hepaticae). Acta Bot Fenn 174: 1-88.

Gradstein SR. 2011. Guide to the Liverworts and Hornworts of Java SEAMEO-BIOTROP. Bogor.

Gradstein SR. 2013. A classification of Lejeuneaceae (Marchantiophyta) based on molecular and morphological evidence. Phytotaxa 100: 6-20

Gradstein SR. 2015. An overview of the genus Schiffneriolejeunea (Marchantiophyta: Lejeuneaceae). Nova Hedw 100 (3-4): 507-524.

Haerida I. 2009. Keanekaragaman suku Lejeuneaceae (Hepaticae, Lumu Hati) di daerah sekitar PPKAB (Pusat Pendidikan dan Konservasi Alam Bodogol) Taman Nasional Gunung Gede-Pangrango, Jawa Barat. Berita Biol 9 (4): 683-691. [Indonesian]

Haerida I, Gradstein SR, Tjitrosoedirdjo SS. 2010. Lejeuneaceae Subfamily Ptychanthoideae (Hepaticae) in West Java. Gard Bull Sing 62 (1): 126-162.

Kariyappa comb. et stat. nov. (Lejeuneaceae) from India. Taiwania 58 (2) 140-145. DOI: $10.6165 /$ tai.2013.58.140.

Kornochalert S, Santanachote K, Wang J. 2012. Lejeuneaceae Subfamily Ptychanthoideae (Marchantiophyta) in Thailand. Crypt Bryol 33 (1) 39-63.

Lee GE, Pócs T, Damanhuri A, Latiff A. 2011. Lejeunea gradsteini (Lejeuneaceae), a new Liverwort species from Mt. Kinabalu, Sabah. Acta Biol Plant Agr 1: 37-51.

Lee GE. 2013. A Systematic Revision of The Genus Lejeunea Lib (Marchantiophyta: Lejeuneaceae) in Malaysia. Crypt Bryol 92: 381 474.

Lee GE, Gradstein SR. 2013. Distribution and habitat of the Malaysian species of Lejeuenea (Marchantiophyta: Lejeuneaceae), with description of Lejeunea tamaspocsii sp. Nov. Polish Bot J 58 (1): 59 69.

Lee GE, Pócs T, Chantanaorrapint S, Damanhuri A, Latiff A. 2014. An account of the genus Lejeunea (Marchantiophyta: Lejeuneaceae) in Thailand, including seven newly recorded species. Crypt Bryol 35 (3): 247-259. doi/10.7872/cryb.v35.iss3.2014.247

Lee GE, Pócs T. 2018. Additions to the distribution of some Palaeotropic Lejeunea (Marchantiophyta) species, with the description of Lejeunea konratii sp. nov. from Fiji. Phytotaxa 349 (1):031-038.

Manju CN, Pócs T, Rajesh KP, Prakashkumar R. 2012. Lejeuneaceae (Marchantiophyta) of the Western Ghats, India. Acta Biol Plant Agr 2: $125-145$.

Mizutani M. 1970. Lejeuneaceae subfamilies Lejeuneoideae and Cololejeuneoideae from Sabah (North Borneo). J Hatt Bot Lab 33: 225-265.

Pasaribu N, Siregar ES, Rahmi W. 2018. Species of leafy liverworts in Protected Forest of Simancik 1, Regency of Deli Serdang, North Sumatera. IOP Conf Ser: Earth Environ Sci 130012051. DOI: $10.1088 / 1755-1315 / 130 / 1 / 012051$

Pócs T. 2011. East African Bryophytes XXIX. The Ceratolejeunea (Lejeuneaceae) species of the Indian ocean islands. Polish Bot J 56 (2): $131-153$

Pócs T, Tuiwama M, Konrat MV. 2011. New Liverwort (Marchantiophyta) records for Fiji Island. Telopea 13 (3): 455-494.

Pócs T. 2013. The Genus Colura (Lejeuneaceae) in New Guinea and in the Neighboring Areas. Chenia 11: 12-38.

Pócs T, Luong TT, Ho BC. 2013. New or little known epiphyllous liverworts, XVIII. Records from the Bidoup-NúiBà National Park,
Vietnam, with the description of Drepanolejeunea bidoupensis, sp. nov. Crypt Bryol 34 (3): 287-298.

Schäfer-Verwimp A. 2006. A new species of Diplasiolejeunea (Lejeuneaceae, Jungermanniopsida) from Sumatra, and a key for the genus in Asia. Herzogia 19: 239-244.

Shu L, Xiang YL, Cheng XF, Wei YM, Wang J, Zhang LN, Li W, Yin XB, Zhang WP, Zhao CX, Peng T, Do TV, Lu TN, Zhu RL. 2017. New Liverwort and Hornwort records for Vietnam. Crypt Bryol 38 (4): 411-445

Singh Deo S, Singh DK.2013. Cheilolejeunea eximia (Lejeuneaceae: Marchantiophyta) - an addition to the Indian Bryoflora from Eastern Himalaya with a note on distribution of the genus in India. NeBIO 4 (4): 52-57.

Singh DK, Singh D. 2016. Epiphyllous liverworts of India: An Overview. Plant Sci Today 3 (2): 157-174. DOI: 10.14719/pst.2016.3.2.228.

Singh SK, Kumar S. 2016. A Preliminary study on liverworts and hornworts of Tripura, North-East India. Nelumbo 58: 130-151.

Siregar ES, Ariyanti NS, Tjitrosoedirdjo SS. 2013. The liverwort genus Marchantia (Marchantiaceae) of Mount Sibayak, North Sumatra, Indonesia. Biotropia 20 (2): 73-80. DOI: 10.11598/btb.2013.20.2.3.

Siregar ES, Ariyanti NS, Tjitrosoedirdjo SS. 2014. Lejeuneaceae anak suku Ptychanthoideae di Hutan Sibayak, Sumatra Utara. Floribunda 4 (8): 218-225. [Indonesian]

Siregar ES, Hannum S, Pasaribu N. 2017. Lejeuneaceae (Marchantiophyta) of Sicike-cike Natural Park, North Sumatra Indonesia. Taiwania 62 (4): 356-362.

Siregar ES, Ariyanti NS, Tjitrosoedirdjo SS. 2018. Plagiochila (Marchantiophyta) of Mount Sibayak North Sumatra. IOP Conf Ser: Earth Environ Sci 130: 012017. DOI: 10.1088/17551315/130/1/012017

Siregar ES, Pasaribu N. 2019. Lepidoziaceae (Marchantiophyta) in Taman Eden 100 Natural Park, North Sumatra Indonesia. IOP Conf Ser: Earth Environ Sci 305: 012013. DOI: 10.1088/17551315/305/1/012013

Siregar ES, Pasaribu N. 2020. Lejeuneaceae (Marchantiophyta) of Taman Eden 100 Natural Park North Sumatera Indonesia. IOP Conf Ser: J Physic: Conf Ser 1462: 012059. DOI:10.1088/17426596/1462/1/012059.

Sukkharak P, Gradstein SR. 2014. A taxonomic revision of the genus Mastigolejeunea (Marchantiophyta: Lejeuneaceae). Nova Hedwigia 99 (3-4): 279-345. DOI: 10.1127/0029-5035/2014/0206

Sukkharak P. 2015. A Systematic monograph of the genus Thysananthus (Lejeuneaceae, Marchantiophyta). Phytotaxa 193 (1): 1-81.

Thiers BM. 1992. A Re-evaluation of Cheilolejeunea subgenus Xenolejeunea. Trop Bryol 5 (1): 10-21.

Wang J, Lai MJ, Zhu RL. 2011. Liverworts and Hornworts of Taiwan: An updated checklist and floristic accounts. Ann Bot Fenn 48: 369-395.

Wang J, Gradstein SR, Daniels AED, Zhu RL. 2014. New synonymy in Ptychanthus striatus (Lejeuneaceae, Marchantiophyta). Phytotaxa 158 (2): 195-200.

Wang J, Zhu RL, Gradstein SR. 2016. Taxonomic revision of Lejeuneaceae subfamily Ptychanthoideae (Marchantiophyta) in China. Bryophytorum_Bibliotheca 65: 1-141.

Zhu RL, So ML. 2001. Epiphyllous Liverworts of China. Nova Hedw Beiheft 121: 1-418.

Zhu RL, Gradstein SR. 2005. Monograph of Lopholejeunea (Lejeuneaceae, Hepaticae) in Asia. Syst Bot Monogr 74: 1-98. 